E. Selecky, A. Klimczuk, Financial Gerontology, [in:] D. Gu, M.E. Dupre (eds.), Encyclopedia of Gerontology and Population Aging, Springer, Cham 2020, pp. 1-5, https://doi.org/10.1007/978-3-31969892-2 192-1.

\title{
Financial Gerontology
}

Erik Selecky

Center for Continuing Education, Technical University, Zvolen, Slovakia

Andrzej Klimczuk

Warsaw School of Economics, Warsaw, Poland

\section{Definition}

Financial gerontology can be defined as investigating relations between finances and aging. Authors such as Neal E. Cutler, Kouhei Komamura, Davis W. Gregg, Shinya Kajitani, Kei Sakata, and Colin McKenzie (Kajitani et al. 2017) affirm that financial literacy is an effect of aging with concern about the issue of finances, as well as stating that it is the effect of longevity and aging on economies or the financial resilience of older people.

\section{Overview}

Financial gerontology dates back to the 1980s when Jozef Boettner and Davis Gregg started to deal with the effects of financial education on population aging (Vitt and Siegenthaler 1996; Cutler 2016). They felt the need to educate older generations about finances and financial services in a professional way. In the year 1986, the first research entity focused on the financial gerontology, "Boettner Research Institute" in the United States, was founded and led by Gregg. The first director of the Institute was Neal E. Cutler. The Institute focused not only on professional education but also on research. The American Institute of Financial Gerontology (AIFG) (2019) was later founded and still exists today. Financial gerontology is a scientific discipline that overlaps with other branches of science such as biology, psychology, sociology, economics, and demography. As a scientific discipline, it evolved due to rapidly advancing technology, medicine, and their impacts on society and the economy. Financial gerontology, as a whole, is perceived as a science aimed at supporting a healthy aging, active lifestyle, selfsufficiency in later life, and in general, improving the quality of life of older people (Timmermann 2018). Financial gerontology does not solely mean the research of older people but rather focuses on the processes of financial planning for aging and longevity (Komamura 2017).

\section{The Effects of Aging and Old Age on Financial Well-Being}

Aging is a natural process involving biological, health, economic, and social changes. It is an 
E. Selecky, A. Klimczuk, Financial Gerontology, [in:] D. Gu, M.E. Dupre (eds.), Encyclopedia of Gerontology and Population Aging, Springer, Cham 2020, pp. 1-5, https://doi.org/10.1007/978-3-31969892-2 192-1.

irreversible process (effect of genetics, the environment, and lifestyle), connected with psychological age (e.g., individual behavioral changes during the process of aging) and sociological age (e.g., termination of employment and social role transition). The challenge of population aging is discussed in many strategic documents around the world, and it is implemented in many programs and statements. Old age is the last stage of the human life cycle. Being aware of an approaching and inevitable end can result in various difficulties relating to the adaptation and coping with later age and age-related changes as well as demand financial education and socialization and, retirement planning (Timmermann 2016a). Coping with aging successfully in terms of financial wellbeing is an essential condition for achieving satisfaction in later life. Old age is accompanied by physical and mental changes arising due to changes in the external as well as the internal environment. All older people can live with dignity and age gracefully, enjoy life in old age, and prevent medical problems. Many of these factors depend upon their personal choice and the way of living which they prefer. Individual approaches to successful aging affect the quality of life to a substantial extent.

\section{The Effect of the Economy on Retirement}

Older citizens can be defined as being citizens who can receive a pension. Terms such as an early pensioner or pensioner with disability are quite common. Pensions received by these people differ from universal basic pensions related to old age. An increase in life expectancy can be seen due to many factors such as the rapid development of technology, electronics, information communication technologies (ICTs), and increasingly effective medicine. The retirement age varies around the world. One of the reasons for this is the various levels of socioeconomic development. For instance, in Germany, the retirement age is 67, whereas, in Slovakia, it is 63 and 55 in Ukraine. Concerning the recent world statistics, Japan's retirement age is the highest at 75 (Komamura 2017).

Pension systems in individual countries must reflect a variety of standards of retirement ages. Pension schemes must be flexible because of gradual changes in human life spans. The role of public and private pension systems must be considered, especially concerning how their influence and the rules of investment appraisal. The term "the problem with longevity" can be perceived negatively mainly from an economic point of view (Allenby 2013; Mitra 2017). Everybody is willing to live as long as possible, but, of course, quality of life plays a significant role. Moreover, negative age stereotypes and agism are already also challenging for financial services advisors, firms, and related financial sectors such as banking and insurances 
E. Selecky, A. Klimczuk, Financial Gerontology, [in:] D. Gu, M.E. Dupre (eds.), Encyclopedia of Gerontology and Population Aging, Springer, Cham 2020, pp. 1-5, https://doi.org/10.1007/978-3-31969892-2 192-1.

(Migliaccio 2019).

The issue of population aging is also affected by migration. The rules in developed countries provide accepting foreign-born people because of social or economic reasons. The economy of a country is also significantly affected by education, and it must be recognized that the percentage of populations with university degrees is getting higher. To a considerable extent, university students continue in their studies and apply for PhD courses. On the one hand, fulltime students are a part of the education system. On the other hand, the retirement age has to be increased gradually. It follows that the productive years of people hiring in secondary education job positions and jobs oriented to manual work are extended, and it is beneficial to the state because of the levied taxes.

\section{Financial Issues in the Context of the Silver Economy}

The term silver economy is very closely related to financial gerontology. The silver economy is used to describe the consumption, production, and distribution of goods and services for the aging population, especially older people (Klimczuk 2016). As the number of older adults increases, the number of older consumers and voters increases as well. States and their economies will have to react and adapt to such changing situations. The more developed the economy is, the higher the purchasing power of seniors is. In the structure of consumption expenditure, Engel's law (Kindleberger 1990) is valid: the more money someone has, the less money they spend on necessities of life such as food and accommodation, but more money they spend on a healthy lifestyle and higher needs such as healthcare, holidays, culture, and charity. Therefore, the fact that an increase in life expectancy can increase health and social care and related expenses can be expected. The significant role of the economy in individual countries must be flexible enough to look at the different angles of such changes. This is an essential task not only for economists and analysts but also for politicians.

\section{Educational Programs Related to the Financial Gerontology}

Systematic education can help enhance theoretical and practical knowledge concerning financial gerontology. Education programs in this area concentrate on people both close to retirement and those already receiving pensions. Other target groups include consultants, lecturers, and teachers. In other words, two groups can be affirmed: those being educated and the educators themselves.

A critical publication in the field entitled Encyclopedia of Financial Gerontology was edited 
E. Selecky, A. Klimczuk, Financial Gerontology, [in:] D. Gu, M.E. Dupre (eds.), Encyclopedia of Gerontology and Population Aging, Springer, Cham 2020, pp. 1-5, https://doi.org/10.1007/978-3-31969892-2 192-1.

by Lois Vitt and Jurg Siegenthaler (1996). The encyclopedia entries were divided into eight main categories: economic and income security; employment, work, and retirement; family and intergenerational issues; financial advice, investments, and consumer services; healthcare and health insurance; housing and housing finance; legal issues and services; and quality of life and well-being. These topics could be included in preparing education courses, seminars, and programs.

The American Institute of Financial Gerontology (AIFG) (2019) is one of the most important institutions that deal with financial gerontology. The AIFG provides education and consulting services for older people and their families. Education is aimed at older generations and understanding their needs. The main focus is on the family and intergenerational aspects, aging, health-related expenses, marketing to people age 50+, and older people's readiness and preparation for later life. Neil E. Cutler, the current president and a principal author in the field of financial gerontology, puts great emphasis on financial planning (Cutler 2008).

In the European environment, there are publications (Gracova et al. 2017; Selecky 2017) that are analyzing seniors' education provided by the Universities of the Third Age. Education concerning finances is oriented toward topics such as how debts arise and how not to become insolvent; financial environment; tips to get finances under control (incomes-expenditures); financial goals; setting money aside; payslips; the tax system; the economy of married couples or partners; personal finances; banking and bank services; how to purchase goods and services effectively; types of loans; savings; investment appraisals; and insurance and insurance products. The term financial literacy is commonly used at the Universities of the Third Age as a synonym to the financial gerontology. However, it cannot be defined precisely when older people are financially literate. It is more about being familiar with finances and financial mechanisms and about the information on how to use them correctly in various life situations.

\section{Future Directions of Research}

As has already been mentioned, financial gerontology concerns both people who are going to receive retirement and those who are already retired and are receiving a pension. A third group consists of consultants, lecturers, and teachers - people specialized in education (Migliaccio 2017). Informal education, for example, further education providing training courses and seminars, should be offered to people just before their retirement. The second target group can be educated at the Universities of the Third Age (Selecky 2017; Klimczuk 2013). Education can be provided by universities, non-governmental organizations, civic associations, 
E. Selecky, A. Klimczuk, Financial Gerontology, [in:] D. Gu, M.E. Dupre (eds.), Encyclopedia of Gerontology and Population Aging, Springer, Cham 2020, pp. 1-5, https://doi.org/10.1007/978-3-31969892-2 192-1.

community centers, towns, and villages or private companies. The third target group could enhance their knowledge using formal education provided by universities, professional associations, and associations focused on the economy or private companies. A flourishing area of research potential might concern the members of the first target group - people just before retirement who need preventing despair and promoting resilience (Timmermann 2016b). The essential research topics cover questions such as how to think about working life, financial planning for the future, retirement, and how to be prepared for old age.

\section{Summary}

Financial gerontology is a young scientific discipline that focuses on the issue of finances, especially the relationships between finances, aging, and older people (Cutler 2008). Financial gerontology covers a range of cutting-edge topics with immense potential not only in the future but also at present. Financial gerontology is necessary to deal with the demographic transition models, life span, and later retirement regarding the economy (Cutler 2016). Financial gerontology is needed to raise awareness of economic and financial issues. Not only developed countries should adapt to changing situations and provide new models for life insurance and pension funds. The transition from the economically active population to the retired population should be supported by various programs, seminars, and courses focused on financial gerontology.

\section{References}

Allenby B (2013) Talking 'bout my generation: the real walking dead. Slate. https://slate.com/technology/2013/10/the-big-problem-with-longevity-oldpeople.html?via=gdpr-consent. Accessed 23 June 2019

Cutler NE (2008) Financial gerontology, family aging, and middle-aged boomers: using the "senior sandwich generation" concept in retirement planning. TIAA Institute, New York, pp 1-14

Cutler NE (2016) Twenty-five for 25: a quarter-century of financial gerontology. J Financ Serv Prof 70:25-33

Gracova D, Spulber D, Selecky E (2017) Universities of the third age in Europe. Carocci, Roma

Kajitani S, Sakata KEI, McKenzie C (2017) Occupation, retirement and cognitive functioning. Ageing Soc 37:1568-1596. https://doi.org/10.1017/S0144686X16 000465 
E. Selecky, A. Klimczuk, Financial Gerontology, [in:] D. Gu, M.E. Dupre (eds.), Encyclopedia of Gerontology and Population Aging, Springer, Cham 2020, pp. 1-5, https://doi.org/10.1007/978-3-31969892-2 192-1.

Kindleberger CP (1990) Engel's law. In: Kindleberger CP (ed) Economic laws and economic history. Cambridge University Press, Cambridge, UK, pp 3-20.

https://doi.org/10.1017/CBO9780511559495.003

Klimczuk A (2013) Universities of the third age in Poland: emerging model for 21st century.

J Educ Psychol Soc Sci 1(2):8-14

Klimczuk A (2016) Comparative analysis of national and regional models of the silver economy in the European Union. Int J Ageing Later Life 10(2):31 -59.

https://doi.org/10.3384/ijal.1652-8670.15286

Komamura K (2017) Longevity across the disciplines: new frontiers in financial gerontology. Keio University, Tokyo. https://www.keio.ac.jp/en/keio-times/features/2017/2/. Accessed 23 June 2019

Migliaccio JN (2017) Planning for the utterly unexpected: advice for the retirement advisor. $J$ Financ Serv Prof 71:32-37

Migliaccio JN (2019) The ageism within and how to counter it. J Financ Serv Prof 73:26-31

Mitra S (2017) Our future - the problem with longevity. HuffPost News.

https://www.huffpost.com/entry/our-future-the-problem_b_14003944. Accessed 23 June 2019

Selecky E (2017) Universities of the third age in Europe - best practice. Technical University in Zvolen, Zvolen

Timmermann S (2016a) Life planning and retirement planning: where do they intersect? J Financ Serv Prof 70:33-36

Timmermann S (2016b) Shocks and loss in retirement: preventing despair, promoting resilience. J Financ Serv Prof 70:34-38

Timmermann S (2018) Financial gerontology: what is it? Do we need it? What can we learn? J Financ Serv Prof 72:37-42

Vitt LA, Siegenthaler JK (eds) (1996) Encyclopedia of financial gerontology. Greenwood Press, Westport 